\title{
Retail Sales Workers
}

National Cancer Institute

\section{Source}

National Cancer Institute. Retail Sales Workers. NCI Thesaurus. Code C122504.

Retail sales workers include both those who sell retail merchandise, such as clothing,

furniture, and automobiles, (retail salespersons) and those who sell spare and replacement parts and equipment, especially car parts (parts salespersons). Both types of workers help customers find the products they want and process customers' payments. 